Kueczkowski, J. \& KueczkowskI, A. (1959). J. gen. Microbiol. 21, 308-311

\title{
The Effect of Infection with Bacteriophage on the Electrokinetic Potential of Rhizobium leguminosarum
}

\author{
BY J. KLECZKOWSKI AND A. KLECZKOWSKI \\ Rothamsted Experimental Station, Harpenden, Hertfordshire
}

SUMMARY: Infection with bacteriophage increased the electrophoretic mobility of pea nodule bacteria (Rhizobium leguminosarum) at pH 7, suggesting an alteration of the bacterial surface. This seemed to occur at about the middle of the latent period.

As the electrophoretic mobility of a bacterium in a constant environment depends on properties of the surface of the organism, alterations in mobility have been used as a means of detecting changes in the structure of the surface. Changes have been detected in this way during the germination of spores and during the initial stages of growth of the vegetative form (Douglas \& Parker, $1958 \mathrm{~b}$ ), at the beginning of growth in a new medium, during transitions between 'smooth' and 'rough' forms (Moyer, 1986), and during treatment with enzymes (Dyar, 1948; Harris, 1953; Douglas \& Parker, 1958a,b) or with bactericidal and related substances (Bradbury \& Jordan, 1942; Cohen 1945). The purpose of this work was to find whether, and if so at what stage, infection with bacteriophage alters the bacterial surface in a way reflected in a change of electrophoretic mobility.

\section{METHODS}

A strain of pea nodule bacteria (Rhizobium leguminosarum) and a corresponding bacteriophage were used. The media and the method of poured plates for obtaining plaques were as previously described (Kleczkowska, 1945). Liquid cultures of the bacteria lysed by the phage, and passed through a Chamberland L3 filter, are referred to as 'stock cultures' of the phage; these were stored at $0^{\circ}$.

Electrophoretic mobility was measured in $\mathrm{M} / \mathbf{1 5}$ phosphate buffer ( $\mathrm{pH} 7$ ) at $0^{\circ}$ in the $2 \mathrm{ml}$. Tiselius cell of a Perkin-Elmer Model $38 \mathrm{~A}$ electrophoresis apparatus under a gradient of $9.5 \mathrm{~V} / \mathrm{cm}$. As visual observation does not distinguish between phage-infected and non-infected bacteria in the same suspension, the optical system of the apparatus could not be used. Instead the mobilities were calculated from results of assays of fluids withdrawn separately from the ascending and descending limbs of the electrophoresis cell after periods of electrophoresis. The mobility of free bacteriophage, which was too dilute to give a visible boundary, was calculated similarly from results of assays. The descending limb and the bottom part of the electrophoresis cell were filled with the fluids to be examined, whereas the ascending limb contained only the buffer. The assays showed the proportions of phage or non-infected 
or infected bacteria which had left the descending limb and entered the ascending limb of the Tiselius cell when electrophoresis ended. Assuming that the tested materials were electrophoretically homogeneous, the distances they moved were computed by multiplying $5 \mathrm{~cm}$. (the length of the limbs of the electrophoresis cell) by the proportions. The bacterial suspensions were stable enough for sedimentation under gravity not to affect them appreciably during the time of electrophoresis.

\section{RESULTS}

One volume of phage stock culture (containing about $10^{9}$ phage particles $/ \mathrm{ml}$. by the plaque count) was added to nine volumes of a $24 \mathrm{hr}$. liquid bacterial culture (containing about $2 \times 10^{8}$ bacteria/ml. by the colony count) so that about half of the total number of bacteria became infected; the mixture was incubated at $25^{\circ}$. The latent period, i.e. the period between adding phage to the bacteria and the lysis of the first cells, lasts $90 \mathrm{~min}$. and is followed by the first step of the logarithmic increase in the number of infective centres, which also lasts for $90 \mathrm{~min}$. To measure the mobility of the bacteria at any desired stage of interaction with bacteriophage, the progress of the interaction was stopped by cooling to $0^{\circ}$. The bacteria were then washed in cold buffer to remove free bacteriophage, suspended in buffer and subjected to electrophoresis usually for about $30 \mathrm{~min}$. The mobility of infected and of non-infected bacteria was then computed from the results of their assays (by the plaque count and by the colony count, respectively) in the fluids withdrawn from the descending and ascending limbs of the Tiselius cell. The mobility of non-infected bacteria was also measured, using bacterial suspensions to which no phage had been added.

Table 1 shows that in each experiment, when bacteria had been incubated for 60 or $120 \mathrm{~min}$. at $25^{\circ}$, the phage-infected bacteria moved faster than noninfected bacteria (Expts. 6-10). When, however, incubation with phage lasted only $\mathbf{3 0} \mathrm{min}$., the mobilities of infected and non-infected bacteria did not differ within the same experiments (Expts. 4 and 5), and comparisons within experiments were much more consistent than comparisons between experiments. Only the difference between the means of mobilities of noninfected and of infected bacteria which had been incubated at $25^{\circ}$ for 60 or $120 \mathrm{~min}$., was therefore tested statistically. A statistical test seemed necessary because of the considerable variation between the results of different experiments. The probability of the two means (0.708 and 0.866$)$ differing only by chance is, by the $t$ test, one in more than a thousand, so that the difference can be taken as highly significant.

The electrophoretic mobility of phage-infected bacteria was obtained by measuring the mobility of infective centres; these would include not only infected bacteria, but also any free phage particles that might have been present in spite of the precautions to exclude them. The mobility of free phage was therefore measured and found to be $c$. $-0.45 \pm 0.02 \mu / \mathrm{sec} / \mathrm{V} / \mathrm{cm}$. It is obvious, therefore, that infection increased the mobility of the bacteria, for the infected bacteria moved faster than non-infected bacteria, whereas free 
phage moved more slowly than either. There seemed to be only one increase, which occurred between 30 and $60 \mathrm{~min}$. of incubation at $25^{\circ}$, i.e. about the middle of the latent period. The timing must, however, be considered uncertain because of the considerable variation between the results of different experiments.

\section{Table 1. Electrophoretic mobilities of non-infected and of phage-infected Rhizobium leguminosarum}

Expts. 1-3 were made with bacterial suspensions to which no phage was added. Expts. 410 were made with mixtures of bacteria with phage incubated at $25^{\circ}$ for indicated periods of time. The mobilities of non-infected bacteria in Expts. 6 and 9 were not estimated because of technical failures.

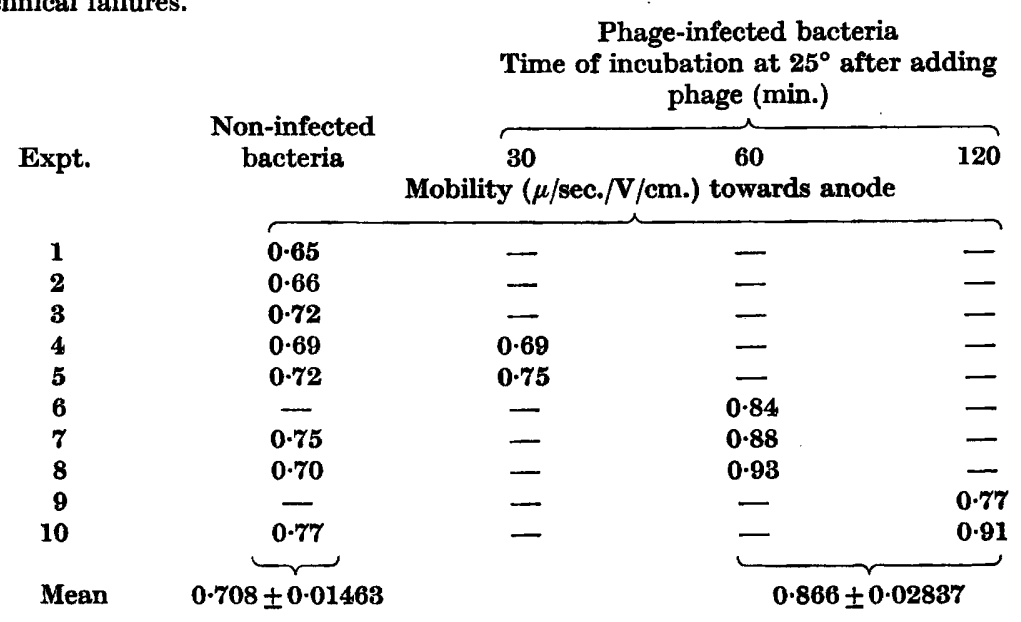

With the system used in this work nothing is known about the progress of phage-host interaction during the latent period. With some coliphages the middle of the latent period corresponds approximately with the end of the eclipse stage, when mature phage particles begin to appear within infected bacteria (Doermann, 1952; Anderson \& Doermann, 1952). If it be assumed that the eclipse stage of the Rhizobium bacteriophage also ends at about the middle of the latent period, the increase in the electrokinetic potential of the bacterial surface would approximately coincide with the end of the eclipse stage.

\section{REFERENCES}

Anderson, T. F. \& Doermann, A. H. (1952). The intracellular growth of bacteriophages. II. The growth of T3 studied by sonic disintegration and by T6cyanide lysis of infected cells. J. gen. Physiol. 35, 657.

Bradbury, F. R. \& Jordan, D. O. (1942). The surface behaviour of antibacterial substances. 1. Sulphanilamide and related substances. Biochem. J. 36, 287.

Conen, S. S. (1945). The chemical alteration of a bacterial surface, with special reference to the agglutination of B. proteus OX-19. J. exp. Med. 82, 133.

Doermann, A. H. (1952). The intracellular growth of bacteriophages. I. Liberation of intracellular bacteriophage $\mathbf{T} 4$ by premature lysis with another phage or with cyanide. J. gen. Physiol. 35, 645. 
Douglas, H. W. \& Parker, F. (1958 a). Electrophoretic studies on bacteria. 2. The effect of enzymes on resting spores of Bacillus megatherium, B. subtilis and B. cereus. Biochem. J. 68, 94.

Douglas, H. W. \& Parker, F. (1958b). Electrophoretic studies on bacteria. 3. The growth cycle of Bacillus megatherium, the behaviour of cells and the changes produced by lysozyme. Biochem. J. 68, 99.

Dyar, M. T. (1948). Electrokinetical studies on bacterial surfaces. II. Studies on surface lipids, amphoteric material, and some other surface properties. J. Bact. 56, 821.

HARris, J. O. (1953). Electrophoretic behaviour and crystal violet adsorption capacity of ribonuclease treated bacterial cells. J. Bact. $65,518$.

KLECZKOWSKA, J. (1945). The production of plaques by Rhizobium bacteriophage in poured plates and its value as a counting method. J. Bact. 50,71 .

Moyer, L. S. (1936). Changes in the electrokinetic potential of bacteria at various phases of the culture cycle. J. Bact. 32, 433.

(Received 20 January 1959) 